\title{
INFLUENCE OF PRODUCT PLACEMENT ON CONSUMER BEHAVIOR: THE MEDIATING ROLES OF CONSUMER RECOGNITION WITH PROGRAM CELEBRITY AND ETHICAL PERCEPTIONS TOWARDS PRODUCT PLACEMENT THAT LEADS TO CONSUMER PURCHASE INTENTION
}

\author{
Asad Ullah Khan 1 \\ Institute of Business \& Management \\ University of Engineering and Technology \\ Lahore, Pakistan \\ Asif Mahmood 2 \\ Assistant Professor \\ Institute of Business \& Management \\ University Of Engineering and Technology \\ Lahore, Pakistan \\ Rab Nawaz Lodhi ${ }^{3}$ \\ Institute of Business \& Management \\ University Of Engineering and Technology \\ Lahore, Pakistan \\ Faisal Aftab ${ }^{4}$ \\ Director Research \\ Bahria University, Islamabad \\ Pakistan
}

\begin{abstract}
Purpose: Product Placement is nowadays popular tool of advertisement. It is very difficult to place the product and synchronize it with the natural environment so that consumer is acknowledged and has positive vibes towards the placed products brand. Objectives of this Research Article are that we have to find relation between Product Placement, Consumer Perception towards ethics of Product Placement, Consumer Recognition with Program Celebrity that leads to Consumer Purchase Intention.

Methodology/Sampling: The study is based on 600 consumers who take part in the study and Quantitative Research methods are used to analyze the results. SPSS 20.0 is used for the purpose of data analysis in this study.

Findings: The results showed that there is a positive relationship between these variables Product Placement, Consumer Perception towards ethics of Product Placement, Consumer Recognition with Program Celebrity that leads to Consumer Purchase Intention and Consumer Purchase Intention.

Practical Implication: This study recommends Brands and their Product Placement strategists to follow the ethical approach in Placing their Product in the movie or Television series use the Celebrity attachment with the Product in a way that there is a Positive affect on the Consumer and our goalto enhance Consumer Purchase Intention is accomplished.
\end{abstract}

Keywords: Product placement, Program Celebrity, Ethical Perceptions, Purchase intention

\footnotetext{
* The material presented by the author does not necessarily portray the viewpoint of the editors and the management of the Institute of Business \& Technology (IBT)

${ }_{2}^{1}$ Asad Ullah Khan

2 Asif Mahmood

3 Rab Nawaz Lodhi

4 Faisal Aftab

(C) IBT-JBS is published by the Institute of Business and Technology (IBT). Main Ibrahim Hydri Road, Korangi Creek, Karachi-75190, Pakistan.
} 


\section{INTRODUCTION}

In Today's world product placement can be considered as the highly influential and important strategy used by the marketers of different corporate of the world. In short and simple statement we can say that product placement factor is consisting of advertiser, marketer or company related content to achieve the specific product target selling goal in a fixed time. Advertiser can merge or place the product into the scenes of the drama, movie or show which is in progress now these days. The term Product placement which is used in one study is defined as "purposeful incorporation of different brands into editorial content".

There is a study that Product Placement is Industry in its own way and 14 billion $\$$ is the amount which is paid by different brands to the fictional screens or we can say movies to promote their products or brands. And the main reason behind that is the new trend which is followed by customers of brands. $66 \%$ of customers mute TV when they saw advertisement, $90 \%$ customers of brands skip the ads in pre recorded media and $78 \%$ of marketers believe that TV advertisement is sharply declining by time .

In a study focus researchers focus on the consumer's attitude toward product placement in the different Hollywood movies e.g. scene in which Tom Cruise is chewing Hollywood chewing gum and using BMW car. They got the result and result was that 70 percent have positive attitude toward this sort of marketing communication strategy, so analyzed that it was preferable for them to watch a commercial of any product before watching a movie. However, we cannot say that results can be as same if compared with the Television sponsorship .

BMW which is from one of the largest car manufacturing companies is having the product placement strategy too and also limited but focused series of its placements in three major films of that time and is now expanded to 20 James Bond films in 40 Years.

One study is also showing that to maximize communication APPLE which is the largest IT Company in the world used product placement strategy more than 100 times annually since its birth time .

There is one more company in competition, which is named by NOKIA in the field of IT and has a big name also used the product placement strategy. In 1995 it showed its cell phone on television drama "Melrose Place" which was on aired at that time. NOKIA has also success in placing its product in a way by the lowest cost product placement a comedy movie named "CLUELESS" and the cost of placing the product was five cell phones only at that time by the company .

Coco Cola and Mercedes Benz very renowned companies of the world stepped back from showing their logo in the Bollywood movie "Slumdog millionaire" both companies do product placement alot but why they stepped back reason behind this was the affiliation of brand with the audience and they do not want to place their product 
in a movies which has impressions of targeting slums of India. Is their audience going to consider this good for the brand or not that was the issue behind the whole decision. Because in the movie Brand was going to be showed below standard line which the brands seek for their targeted audience so the brands stepped back and did not placed their product in the movie.

A gender study on product placement strategy based on gender showed that women are more sensitive about product placements in movie than men and this help to place the products in a way that instigate the will of the women community that leads to purchase behavior.

One more study revealed that product placement strategy of Guns, Power and Security factor if seen as whole is more attractive and popular among the women due to the security thing because women are more inclined toward this factor so we can use this factor which can instigate the women communities will to do purchase .

In one study it was focused that how the targeted audience or segment can ethically get the main message without going to be vulgar or vague with the product placement strategy especially with the gender issues that the feminine population is facing nowadays in the product placement technique in the media sector nowadays. e.g. A car company having a new launch of car and stand a female model with extreme short dress which is approximately vulgar or unethical to advertisement technique or a clothing company shows vulgar dresses at a fashion show to promote any product at show just for the purpose to get more money and leaving ethics behind.

Another product placement example and the study which we are going to take is from a Pakistani drama "BULBULAY" which has achieved highest TRP Ratings (8.0) in the Television history which is more than any other comedy drama and have won 3 consecutive Comedy Drama Awards in 3 years consecutively with its 300 episodes

Nowadays it is difficult for the strategists nowadays to implement efficiently the strategy of Product Placement. There are certain flaws related to that which can be seen in the implementation of this strategy in Pakistan media industry. We can see that this strategy is implemented but the scenario of implementation of this strategy if compared to International media is too much vague that customer instead of liking it considers is as aggressive move from the organization and consider it as unethical move of advertising by the brand.

This Article is going to help the strategists of Product Placement in the following main perspectives:

$\S \quad$ Implementation the product placement strategy in efficient way and how Product Placement can be more efficient by following the ethical standards and how Program Celebrity is going to help in better grabbing the Consumer intention to purchase the Product.

$\S \quad$ Main functions, points, examples and Discussions from the Past studies Vol. 12, No. 1, (Spring 2016) 
are also going to help to better understand the Product statement strategy and what are its roots which can better help to understand the whole scenario of implementing the Product statement strategy in a way that leads to create win situation for both the Brand and the Movie or TV series.

By collecting data from 600 participants we focused to find the relation between Product Placement, Consumer ethical Perceptions towards the Product Placement, Consumer Recognition with the Program Celebrity that leads to Consumer Purchase Intention.

Quantitative analyses have been used to find the relation the relation between variables and SPSS 20.0 is used for data analysis. Further this paper has been divided as Literature Review, Conceptual Model, Methodology, Results and Discussions, Conclusion and Implications of Research.

\subsection{Problem Statement}

- How Influence in the mind of consumer about Product Placement is affected by identification with celebrity and ethical perceptions towards product placement that leads to purchase behavior?

\section{LITERATURE REVIEW}

By time the definition of Product Placement has been evolved from "The practice of placing brand name products in movies as props". Whereas Lehu and Bressoud claimed that the use of product placement started with time in the novels and then after in the moving pictures with no sound then in the Radio, Television and Internet and we can say no medium of communication was left by time.

Product placement was mostly practiced through the use of commercial mediums which were sponsored by the brands which were on their back for the purpose to get exposure for their product and increase their sales.

In 1960's, Hollywood movie producers were using the Cigarettes and liquor on sets of movies as the props as the hope of bring the movie close to the reality and close the gap which is existing in between them but the product placement strategy was at the beginning at that time if analyze and ethics were not defined.

During the last decade we can see product placement strategy growth if compared to past in the use of Television sponsorship specially in North American Media where we can say that this industry is not even doubled but tripled by night. For the Firms television medium is an alternative media for the purpose of communicating their products with the customers at different mediums to target their segments to increase sale of products. Whereas the difficult thing is that how the product can be placed in the program efficiently because there are no set rules or standards for that and at the end that is Product Placement which can be positive as well as negative if analyzed from the results perspectives by time . 
In one study Hollywood actor John Wayne, Spencer Tracy and Clark Gabl were paid 3 million dollar each at that time for the purpose to promote the smoking factor at that time in the movies which was actually product placement strategy by cigarette brands, but nowadays smoking is considered unethical but these factors are instigating still today's youth in moving toward the smoking habit which has negative affects afterwards.

In Hollywood, we can see that all the James Bond movies are using many CAR Models which are basically a product placement contract between James Bond Movies and many car manufacturing companies of the world. The Cars which were used in the James Bond movies were following: ALFA Romeo, AMC, Aston Martin, Audi, AvtoVAZ, Bentley, BMW, British Leyland/Rover/MG, Ford Motor Company, (GM) General Motors, Jaguars Cars, Land Rover, Lotus, Mercedes-Benz, Rolls-Royce, Saab.

In a study it was discussed that in the product placement strategy it is necessary for the theme of the Product Placement which should stay in natural everyday touch of its setting or we can say theme of the drama or movie to be stay closer to reality during the Product Placement. Because without this it would be so odd that characters entering into restaurants malls without having name on them or having blank titles more highlighted.

In one study it was discussed that how women have the purchase intention and what factors cause the purchase intention from those factors there was celebrity recognition by the customers. Because when they saw Loral cosmetics used by some famous celebrity used in any movie or drama they have the purchase intention and they move to purchase the product for their own satisfaction to look like that celebrity.

In today's world we can say Product Placement can be done by digitally placing the product at any place from any corner of the world through the internet on social media or any sites for the purpose to broadcast on television. So some critics believe that products which were not the part of the scene were added for the specific audience can create biasness for the other audience at the same time but the fact is that the original scene is not having the material added by the product placement which is added for the special audience.

In one study it was revealed that Celebrity Endorsement or ethical relation with the product placement strategy does not matter if compared, if there is an urgent desire for the purpose to buy a product from anywhere that stands in the scenario of impulse buying. This thing is also included in Impulse buying factor by the customer who is said as "A sudden or immediate buying intention that rises in mind".

In one more study stated that product placement is that much effective that if we are watching a Television program and watch a Vase in it which is placed on the table and is prominent or showing in the back. If we really like this product placement of Vase our feelings are that much provoked that we go on online shopping site and 
see for the same Vase if it is available for sale.

In a study it is stated that advertisement or celebrity endorsement is seen as a fountain of greed and materialistic approach and they also accused advertisement of destroying and damaging public manners and sensibilities and of exploring stereotyping about gender, race or body type and if we analyze it has positive and negative aspects from both sides if compared.

In a study it was revealed that Products which are poorly placed or poorly integrated into the TV program or a movie it is going to get a resistance from the customers because customers today are more aware about the knowledge about what is right and what is not and they want the quality in the entertainment experience even in any way of entertainment media they choose by time .

The main and potential benefits are going to be received after the product is placed in drama or a movie and the sales are going to be increased by $65 \%$ which is a big number if compared from the sales point of view.

One more study reveals that if there is two groups are taken one are of children and the other is of men it is clear that children are the one who cannot differentiate in the ethical terms in product placement and advertising whereas in case of men if compared to children they can easily understand, so market campaign is for those people who are well informed and can understand the risks and benefits affiliated or associated with the products which are placed in the advertisement of that product .

Furthermore in a study it was revealed that Consumers which are naive by nature and which do not have any idea about the product placement strategies and are totally intrinsic in nature should not be targeted by the companies through product placement or celebrity endorsement strategies, this strategy violates principles of being fair in advertisement or Product Placement strategy .

In a study it was revealed that the usage of dead celebrities pictures, names, things or belongings in a movie, Television drama or show in many aspects of marketing, product placement and celebrity endorsement are also from one of marketing strategies used by the strategists, the heirs of the dead celebrity receives a huge amount of money and that is an ethical issue raising these days. This trend raised in America and the reason behind this is the ageing of baby boomers in society which are grownups and even now still following that celebrities which are no more alive. As far this practice is ethical or unethical this is still controversial if we analyze from different perspectives. There are many Hollywood celebrities who are still being used by big brands of the Corporate in their brands promotion and the biggest example is Marilyn Monroe who is still endorsing the Mercedes Car brand even she is not alive .

In a study it was clearly stated that celebrities which are going to be used with the Product Placement strategy should not be Controversial because there is going to be a negative impact on the customer and he is going to consider it as unethical and 
the celebrities who are using the Product in the movie or product is placed in their background it matters that celebrities are credible or not and either they are suitable for the purpose of Product placement or not .

\section{THEORETICAL FRAMEWORK}

To understand the Logical linkage between the variables in study Theoretical framework is going to help. It will to understand the affect of variables on each other and their relationship and how the affect is going to be in a way that relates to our study or proves it. In short theoretical framework helps all the researchers that how the Hypothesis can be formed and test the relation between the presented variables and expand our knowledge with the presented situation. In short we can say theoretical framework help us to understand the association between the presented variables.

There are different studies in which Product Placement strategies have been discussed. And many factors of placing that strategy has been described by the strategists. But we can see that in our study Product Placements relation with the Consumer perception towards ethics of Product Placement is presented but Product Placements relation with Consumer recognition with Program celebrity has also been discussed. And how these variables are associated with each other and lead towards the Consumer intention to Purchase is described in the model below: (See Figure 1 in Appendix)

\subsection{Hypothesis:}

$\S \quad$ H1: There is a positive relation between product placement and consumer purchase intention.

$\S \quad \mathrm{H} 2$ : There is a positive relation between product placement and consumer perception towards ethics of product placement.

$\S \quad$ H3: There is a positive relation between product placement and consumer identification with program celebrity.

$\S \quad \mathrm{H} 4$ : There is a positive relation between consumer perception towards product placement and consumer purchase intention.

$\S \quad \mathrm{H} 5$ : There is a positive relation between consumer identification with program celebrity and consumer purchase intention.

\section{METHODOLOGY}

\subsection{Sample and Data Collection:}

\subsection{Targeted audience: General public}

\subsection{Sample: 600}

The study examines in product placement strategy the role of Consumer perception towards ethics of product placement and Consumer Identification with Program celebrity in enhancing the Consumer Purchase Intention. The individuals we selected are from customers/consumers of different brands. The data collection is 
through self administered structured questionnaire technique. A total of 600 questionnaires is going to be distributed among the individuals. Among the distributed questionnaires in the field only 564 completed questionnaires were received back with a response rate of $94 \%$.

\subsection{Instruments and Measures}

Cluster Sampling: Because we are targeting general public of different cities and it will be difficult for us to get every part of city included in our survey so we are going to use cluster sampling technique so that we can conduct survey on the different random sites which represent the whole population of cities.

\section{SPSS 20.00 is used for the purpose of data analysis}

\subsection{Procedure}

\section{Quantitative analysis}
a) Reliability
b) Correlation
c) Regression

\section{PERFORMING QUANTITATIVE ANALYSIS:}

(See Table 1 in Appendix)

\section{RESULTS}

Our results are showing that our study is proved that our variables which are Product Placement, Consumer Perception towards ethics of product placement, Consumer identification with the program celebrity and Consumer Purchase intention has a positive relation between each other. If we see the Reliability analysis which is showing that our variables are strongly reliable, If Correlation analysis is analyzed it is showing that there is Strong, Moderate and Weak Linear relation between our variables and Regression analysis is showing that our variables if analyze the affect of Independent variables through mediating variables on Dependent Variable is positive so this shows that there is a positive relation between all these variables. Furthermore, Hypothesis is going to be tested for the purpose to prove our study. And these hypotheses are as under:

\section{- H1: There is a positive relation between product placement and consumer perception towards ethics of product placement:}

As we can see that relation between product placement and consumer perception towards ethics of product placement can be seen in many studies. For example Use of dead celebrities, name, pictures and belongings to attract the customers but this topic 
of dead celebrities promotion for our products is controversial so it is related to product placement and consumer perception towards ethics of it either it is ethical or not .

In our study we can see that the reliability of the variable Product placement (0.93) and Consumer Perception towards ethics of product placement (0.84) which shows they are strongly reliable and then if we moves toward to find the relation between these variables through correlation analysis we can see that the result of both variables is 0.699 which shows they have strong (positive) linear relationship. This is proving the point of study that children and men both are affected by the product placement but if compare men have more knowledge of brands and technicalities of different products so they are more affected but children can be drag from the positive side if the Product Placement is manipulating their thoughts.

And then afterwards in our study when we analyze the affect of Consumer perception towards ethics of product placement we can see the result in regression analysis where $P$ value is 0.01 which is significant and showing that product placement has affect on the consumer perception about ethics of product placement.

The above discussed results are showing that there is a positive relation between product placement and consumer perception towards ethics of product placement. So hypothesis is accepted.

In one more study in which we talked about smoking celebrities in the movies and they were highly paid for that whereas smoking is considered unethical nowadays and has negative impact on the young generation so it's all about the consumer perception about the ethics of product placement.

\section{- H2: There is a positive relation between product placement and consumer identification with program celebrity:}

As we can see that the relation between product placement band consumer identification with program celebrity can be seen in many studies. For example dead celebrities which are no more but still endorse brands and example is Marlyn More endorsing Mercedes.

And John Wyne, Bette Davis and Betty Gable who promoted smoking in different movies and were paid 3 million dollars at that time here we can see that Consumer identification with program celebrity is prominent.

In our study we can see that the reliability of the variable Product placement (0.93) and Consumer identification with program celebrity (0.81) which shows they are strongly reliable and then if we moves toward to find the relation between these variables through correlation analysis we can see that the result of both variables is 0.709 which shows they have strong (positive) linear relationship. 
This proves the old studies and in one study they stated about James Bond using different brands of cars in movies which is example of product placement and consumer recognition with program celebrity. And the cars which were placed in Bonds movies were BMW, Mercedes, ALFA Romeo, Bnetley, General Motors , Aston Martin and many more .

And then afterwards when we analyze the affect of Consumer identification with program celebrity we can see the result in regression analysis where $\mathrm{P}$ value which is 0.00 which is significant. The above discussed results are showing that there is a positive relation between product placement and Consumer identification with program celebrity. So hypothesis is accepted.

\section{- H3: There is a positive relation between consumer perception towards ethics of product placement and consumer purchase intention:}

We can see that the relation between consumer perception towards ethics of product placement and consumer purchase intention in many studies. In one study it was stated that if the women see the celebrity in movie using cosmetics product and women see her as a benchmark for them in terms of being like her. But when we see the feminine approach used to promote this and vulagrity that would be unethical but this appeals the customer and the purchase intention is raised but customer can repel and ignore the product as well.

We can see that the reliability of the variable Consumer perception towards ethics product placement (0.84) and Consumer purchase intention (0.75) which shows they are strongly reliable and then if we moves toward to find the relation between these variables through correlation analysis we can see that the result of both variables is 0.509 which shows they have moderate uphill (positive) relationship.

In one study explained that if a car company wants to promote a car and he is just promoting it with a lady with un appropriate too short dress it would be considered unethical by customers and can cause decline in consumer purchase intention.

But in one more study James Bond promote the cars in Bond movies which show product placement can be ethical and by ethically we can trigger the consumer purchase intention..

And then afterwards in our study when we analyze the affect of Consumer perception towards ethics product placement on consumer purchase intention we can see the result in regression analysis where $P$ value is 0.05 which is significant. The above discussed results are showing that there is a positive relation between Consumer perception towards ethics product placement and consumer purchase intention. So hypothesis is accepted. 


\section{H4: There is a positive relation between consumer identification with program celebrity and consumer purchase intention:}

We saw many studies related to defining relation between consumer identification with program celebrity and consumer purchase intentions. From these studies in one it is described how dead celebrities are still endorsing and promoting brands for the corporate and how their heirs are still getting the huge amounts that showed the consumer identification with the program celebrity and consumer purchase intention.

In our study we can see that the reliability of the variable Consumer identification with program celebrity (0.81) and Consumer purchase intention (0.75) which shows they are strongly reliable and then if we moves toward to find the relation between these variables through correlation analysis we can see that the result of both variables is 0.818 which shows they have strong uphill (positive) linear relationship.

We can see in James Bond movies promoted many cars and we can see that these cars were from bigger brands like Mercedes, BMW, Bentley etc. So this also proving the relationship between consumer identification with the program celebrity and customer purchase intention. Because customers follow his celebrity and have intention to purchase the cars that Bond used in movies.

And then afterwards In our study when we analyze the affect of Consumer identification with program celebrity on consumer purchase intention we can see the result in regression analysis where $\mathrm{P}$ value is 0.012 which is significant. The above discussed results are showing that there is a positive relation between Consumer identification with program celebrity and consumer purchase intention. So hypothesis is accepted.

\section{H5: There is a positive relation between product placement and consumer purchase intention:}

Studies have already shown relation between product placement and consumer purchase intention. In one study it was stated that Apple is now focusing more on the product placement and this strategy is increasing 100 times annually which shows that product placement has an impact on consumers so that is the reason Apple is using this strategy because it enhance customer purchase intention.

We can see that the reliability of the variable Product placement (0.93) and Consumer purchase intention(0.75) which shows they are strongly reliable and then if we moves toward to find the relation between these variables through correlation analysis we can see that the result of both variables is 0.372 which shows they have weak uphill(positive) linear relationship.

In a study revealed that NOKIA is using this strategy from many years and focusing towards this strategy to approach its customers. This shows that product placement is used by NOKIA because it is beneficial for the Brand to enhance the 
consumer purchase intention which shows these variables have positive relation.

Afterwards in our study when we analyze the affect of Product placement on consumer purchase intention we can see the result in regression analysis where $\mathrm{P}$ value is 0.00 which is significant. The above discussed results are showing that there is a positive relation between Product placement and consumer purchase intention. So hypothesis is accepted.

BMW in a study used to place its cars in BOND movies and it also focus on this strategy to enhance its customers intention to purchase product which shows that there is a positive relation between product placement and customer intention to purchase product .

\section{DISCUSSION, CONCLUSION AND EXPECTED RESEARCH IMPLICATIONS}

\subsection{Discussion}

Is Product Placement Strategy based on the factors of Consumer Perception about the ethical placement of products and Consumer recognition with Program celebrity that leads to Consumer purchase Intention? Because we have studied many articles and have many examples in our research paper but how Product Placement is more affective and how Western media and World Media is using this strategy by focusing on the Consumer Perception towards ethics of product placement and consumer recognition with the program celebrity that leads to Consumer purchase Intention.

Strong Impact of Product Placement: According to a study that Product Placement is Industry in its own way and 14 billion $\$$ is the huge amount which is paid by different brands to the fictional screens or we can say movies to promote their products or brands. And the main reason behind that is the new trend which is followed by customers of different brands is that $66 \%$ of customers mute their TV when they saw advertisement, $90 \%$ customers of brands skip the ads in pre-recorded media if watching and $78 \%$ of marketers believe that TV advertisement is sharply declining by time and is going to have low worth in future.

NIKE and PEPSI: (Movie name: Back to future) In this movie "Back to future" we can see the clip where Marty Mcfly is holding the shoe and NIKE product is prominent in the picture. Now if we talk about PEPSI we saw in the movie that the Marty Mcfly was having the newer version of PEPSI in movie when he moved to past 1955 and even having the PEPSI when he moved to future in 2015. This is also a Product Placement strategy by company .

Ray Ban: (Movie name: Top Gun) In the movie Top Gun we can see in a clip that Aviators and Tom Cruise success of mission and Tom Cruise was wearing glasses of Ray Ban and at that time Ray Ban used the Product Placement Strategy.

OMEGA, LEXUS AND GAP: (Movie name Minority Report) We can see in 
the movie that Tom Cruise is trying to solve a murder case and there are endless close-ups on the OMEGA watch and he is using LEXUS prototype as convenience and GAP for the purpose of shopping. Here we can say that they used the product placement strategy.

BMW: (Movie name GOLDEN EYE) We can see in the movie "Golden Eye" 1995 blockbuster that BMW placed its car BMW Z3 Roadster. BMW paid 3 million $\$$ to place its Product in the movie which is a Product Placement Strategy by the company and saw 240 million $\$$ advance sales .

Fedex and Wilson: (Movie name Cast Away) In the movie "Cast Away" we can see that Tom Hanks was using Fedex packages to survive after the disaster and that's an example of Product placement by the company and Wilsons Ball was also present which was also the same strategy of Product Placement.

Fair \& Lovely: (Movie name Jawani phir nahi ani) We can see that now even Pakistani movie Fair \& Lovely placed their Products name in the song performed by Sohai which is also and example of Product Placement strategy.

Cornetto (Unilever) \& Habib Bank Ltd: (Movie name Karachi se Lahore) In the movies we can see that how Cornetto ice cream brand by Uni-lever and Habib Bank Limited placed their products and brand name in the movie which is also an example of product placement by the companies of Pakistan.

\section{CONCLUSION}

In our study we were able to find the relation between the variables which are Product Placement, Consumer Recognition with Program Celebrity and Consumer Perception towards ethics of product placement and how they affect each other in which manners. And what are their roles in supporting each other. Results were positive and showing that our study has the edge that it is not even proving the past studies but also giving a new dimension that how much Product Placement strategy is emerging and is having more worth than advertisement nowadays. Product Placement has entered into a new era and we can see that how Hollywood has benefitted by this strategy in the Past and how better they are now at placing products in their movie and dramas and we can also see that even Pakistani Media Industry is now even following the Product Placement strategy in movies and this is more positive towards the media industry and Brands who want to get their brands the exposure are now getting edge through this strategy and by following the Celebrity usage and ethical standards which rise the Consumer purchase intention.

\subsection{Expected Research Implications}

$\S \quad$ The findings of study are important in guiding how ethical perspectives and celebrity recognition help in motivation of purchase behavior in consumers during the Product consideration for buying purpose. 
$\S \quad$ Purchase intention can be analyzed in consumers when ethical standards are followed and celebrity recognition is prominent and consumers feel very comfortable in perceiving the soft image in the mind of consumers about the product.

$\S \quad$ Findings have the points related to Product Placement which follow ethical standards and celebrity recognition techniques which can help the Product Placement strategists of the Brands in areas of product placement for different Brand Products in different movies and dramas nowadays.

$\S \quad$ This research is providing direction for the future research in area of topic.

\section{REFERENCES}

Abdurab, A. (2014, 09 08). Pak media awards. Retrieved 12 03, 2015, from pakmediaawards.com: http://pakistanmediaaward.com/

Ansons, T. L., Wan, F., \& Leboe, J. P. (2010). The Influence of Immersion on Product Placement Effectiveness: A Synthesis and Review of Product Placement in Traditional and Digital Media. In M. S. Eastin, T. Daugherty, \& N. M. Burns, Handbook of Research on Digital Media and Advertising: User Generated Content Consumption (pp. 109-124). IGI Global.

Astous, A. d., \& Seguin, N. (1998).

Aydin, M., \& Soba, M. (2013). Product Placement Efficiency in Marketing Communication Strategy.

Azhar, S. (2015, 08 04). The express Tribune blogs. Retrieved 12 03, 2015, from blogs.tribune.com.pk: http://blogs.tribune.com.pk/story/28856/karachi-se-lahorea-one-man-show-of-hilarity/.

Brodesser-akner, C. (2008, 11 06). Advertising Age. Retrieved 12 03, 2015, from AdaAge: http://adage.com/article/madisonvine-news/coke-mercedes-avoidgritty-film-cameos-slumdog/132301/

Brunner, J. S. (2008, 08 26). Cracked. Retrieved 12 03, 2015, from Cracked.com: http://www.cracked.com/article_16574_the-10-most-shameless-productplacements-in-movie history.html.

Erik. (2011, 01 13). Brands and Films. Retrieved 12 03, 2015, from Brands and Films : http://brandsandfilms.com/2011/01/top-40-product-placements-of-all-time$10-1 /$.

Eugene. (2015, 04 02). Newyork Film Academy ltd. Retrieved 12 02, 2015, from Newyork Film Academy ltd student resource: https://www.nyfa.edu/studentresources/product-placement-movies-5-blatantly-obvious-examples/. 
Gianluigi, G., \& Peluso, A. M. (2010). Acceptance of Product Placement in Italy: Effects of Personality.

Grey, J. (2013, 05 19). Business Insider. Retrieved 12 03, 2015, from BusinessInsider.com: http://www.businessinsider.com/15-worst-movie-product-placements-2013$5 ? \mathrm{op}=1$

Hattab, M. A. (2008). The Ethical Dilemma of Advertisements.

Hudak, K. C. (2014). A Phantasmic Experience: Narrative Connection of. Culture, Theory and Critique, 383-400.

Hudson, S., \& Elliot, C. (2013). Measuring the Impact of Product Placement. Journal of Food Products Marketing, 176-200.

Jackson, M. (2015, 12 01). James Bond vehicles. Retrieved 12 03, 2015, from Wikipedia: http://en.wikipedia.org/wiki/List_of_James_Bond_vehicles Jakoby, W., \& Huuva, J. (2005).

Jan, K., \& Martina, K. (2013). Product Placement: A Smart Marketing Tool. Journal of Competitiveness , 98-114.

Kaijansinkko, R. (2003). PRODUCT PLACEMENT IN INTEGRATED MARKETING COMMUNICATIONS STRATEGY . Kamleitner, \& Jyote. (2013).

Madhavaram, S. R., \& Laverie, D. A. (2004). Exploring Impulse Purchasing on the Internet. ASSOCIATION FOR CONSUMER RESEARCH/Advances in consumer research .

Margie. (2008, 09 26). MailOnline. Retrieved 12 03, 2015, from Daily Mail.co: http://www.dailymail.co.uk/news/article-1061713/Revealed-The-Hollywoodstars-paid-thousands-promote-smoking.html.

Mukherjee, D. (2009). Impact of Celebrity Endorsements on Brand Image. Social science research network .

Muruganantham, G. .., \& Bhakat, R. S. (2013 ). A Review of Impulse Buying Behavior. International Journal of Marketing Studies , 149-160.

Nebenzahl, \& Secunda. (1993).

Sammiudin, S. (2015, 09 08). Aurora . Retrieved 12 03, 2015, from Aurora.dawn.com: http://aurora.dawn.com/news/1141195.

Sekaran, U., \& Bougie, R. (2013). Research Methods for Business: A Skill-Building Approach, 6th Edition. Southern Illinois University,Carbondale: John Wiley \& 
Tiwsakul, R. A., \& Hackley, C. (2006). Young Thai and Uk Consumers' Experiencesof Television Product Placement- Engagement, Resistance and. ASSOCIATION FOR CONSUMER RESEARCH , 372-377.

Yang, D. J., Huang, K. C., \& Feng, X. (2011). A Study of the Factors that Affect the Impulsive Cosmetics Buying of Female Consumers in Kaohsiung. International Journal of Business and Social Science , 275-282.

\section{APPENDIX}

Independent Variable $\quad$ Mediating Variables $\quad$ Dependent Variable

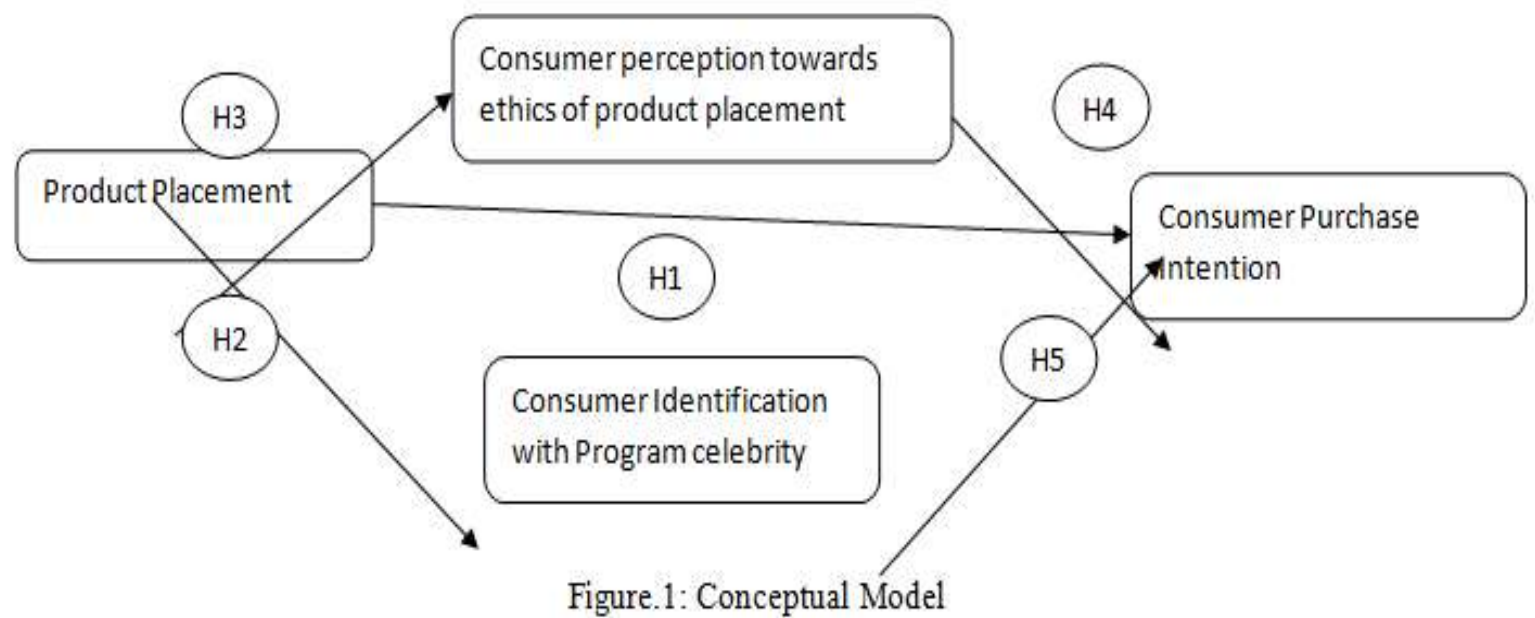

Table 1: Reliability Analysis

\begin{tabular}{|l|l|l|}
\hline No & Variable & Cronbach Aplha \\
\hline 1 & Product Placement & 0.93 \\
\hline 2 & Identification with Program & 0.81 \\
\hline 3 & Ethics of Product Placement & 0.84 \\
\hline 4 & Purchase Intentions & 0.75 \\
\hline
\end{tabular}


Table 2: Correlation Matrix

\begin{tabular}{|c|c|c|c|c|c|c|}
\hline & Mean & S.D & $\begin{array}{l}\text { Product } \\
\text { Placement }\end{array}$ & $\begin{array}{l}\text { Ethics } \\
\text { Placement }\end{array}$ & $\begin{array}{l}\text { of Identification } \\
\text { with Program }\end{array}$ & $\begin{array}{l}\text { Purchase } \\
\text { Intentions }\end{array}$ \\
\hline $\begin{array}{l}\text { Product } \\
\text { Placement }\end{array}$ & 3.30 & 0.79 & 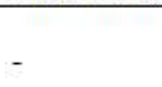 & 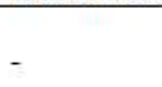 & $x_{1} x_{0}=0$ & 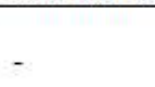 \\
\hline $\begin{array}{l}\text { Ethics of Product } \\
\text { Placement }\end{array}$ & 2.65 & 0.41 & $.699^{* *}$ & - & - & - \\
\hline $\begin{array}{l}\text { Identification } \\
\text { with Program }\end{array}$ & 3.15 & 1.83 & .709 & .541 & - & - \\
\hline $\begin{array}{l}\text { Purchase } \\
\text { Intentions }\end{array}$ & 2.67 & 0.97 & $.372^{* *}$ & .590 & .818 & - \\
\hline
\end{tabular}

**. Correlation is significant at the 0.01 level (2-tailed).

Table 3: Regression Analysis

\begin{tabular}{|c|c|c|c|c|c|c|c|}
\hline Path & & & Estimate & S.E. & C.R. & $\mathbf{P}$ & Decision \\
\hline Ethics of Product Placement & $<$ & Product Placement & 0.449 & .045 & 9.96 & 0.01 & Accept \\
\hline $\begin{array}{l}\text { Identification } \\
\text { Program/celebrity }\end{array}$ & $<$ & Product Placement & 0.063 & .056 & 1.12 & 0.00 & Accept \\
\hline Purchase Intentions & $<$ & Product Placement & 1.483 & .208 & 7.14 & 0.00 & Accept \\
\hline Purchase Intentions & $<$ & $\begin{array}{l}\text { Ethics of Product } \\
\text { Placement }\end{array}$ & 1.702 & .322 & 5.28 & 0.05 & Accept \\
\hline Purchase Intentions & $<$ & $\begin{array}{l}\text { Identification with } \\
\text { Program/celebrity }\end{array}$ & 0.401 & .258 & 1.55 & .012 & Accept \\
\hline
\end{tabular}

Note: GFI 0.994 , AGFI 0.940 , CFI 0.998, RMSEA 0.591 